\title{
Bramy Miłosierdzia Nadzwyczajnego Jubileuszu Miłosierdzia w sieci ośrodków pielgrzymkowych Polski
}

\author{
Doors of Mercy of the Extraordinary Jubilee \\ of Mercy in a network of pilgrimage centres in Poland
}

\begin{abstract}
The Extraordinary Jubilee of Mercy announced by Pope Francis lasted in the Catholic Church from 8 December 2015 to 20 November 2016. In accordance with the Holy Father's decision, approximately 10 thousand Holy Doors - Doors of Mercy were opened in all Catholic Church dioceses during the Jubilee Year. In these doors, the faithful could obtain complete indulgence. In Poland, a total of 669 churches or chapels were pronounced Churches of the Jubilee Year of Mercy by local ordinaries. Doors of Mercy were opened in those churches. These churches included all cathedrals of the Latin Catholic Church (42 cathedrals) and two cathedrals of the Ukrainian Greek Catholic Church, and: 319 shrines, 90 parish churches or filial churches of Divine Mercy, 23 churches of the Most Sacred Heart of Lord Jesus, 10 churches of St. Faustina Kowalska, 10 hospital chapels, 4 prison chapels, two convent chapels, one chapel at the Hospice Home, one chapel of the Border Guards and one chapel at the shelter for the homeless. This paper is aimed at quantitative presentation of the Doors of Mercy of the Extraordinary Jubilee of Mercy in Poland, the analysis of spatial arrangement of Doors of Mercy in the sacred space of Poland, and the grouping of Doors of Mercy with regard to pilgrimage centres in Poland, considering the spatial range of impact, patronage and rank of shrines. The presentation of research results mainly makes use of a dynamic and comparison method, cartographic presentation methods (thematic map and choropleth map), and statistical methods.
\end{abstract}

Keywords: Doors of Mercy, Extraordinary Jubilee of Mercy, Poland 


\section{Wprowadzenie}

W dniu 11 kwietnia 2015 r., podczas obchodów święta Bożego Miłosierdzia w Bazylice św. Piotra w Watykanie, papież Franciszek uroczyście ogłosił, że 8 grudnia 2015 r. w Kościele katolickim rozpocznie się Nadzwyczajny Jubileusz Miłosierdzia, a jego obchody będą trwały do 20 listopada 2016 r. Przed Świętymi Drzwiami papież odczytał także bulle „Misericordiae Vultus” ogłaszającą Rok Miłosierdzia, w której postanowił, aby w III Niedzielę Adwentu 2015 r. „w każdym Kościele lokalnym, w katedrze, która jest Kościołem-Matką dla wszystkich wiernych, bądź też w Konkatedrach lub też w innych kościołach o szczególnym znaczeniu, została otworzona na cały rok taka sama Brama Miłosierdzia. Zależnie od decyzji biskupa ordynariusza będzie ona mogła być otworzona również w sanktuariach, nawiedzanych przez wielu pielgrzymów, którzy właśnie tam bardzo często doświadczają w sercu łaski i znajdują drogę do nawrócenia. Każdy zatem Kościół lokalny będzie bezpośrednio zaangażowany w przeżywanie tego Roku Świętego, jako szczególnego momentu łaski i odnowy duchowej. Jubileusz będzie więc obchodzony zarówno w Rzymie, jak i w Kościołach lokalnych, jako widzialny znak komunii całego Kościoła" (www 1). W Liście przed Jubileuszem Miłosierdzia papież Franciszek pamiętał także o osobach chorych, starszych i samotnych, którzy nie są w stanie wyjść $\mathrm{z}$ domu - dla nich „przeżywanie z wiarą i radosną nadzieją tego momentu próby, poprzez przyjęcie komunii św. lub uczestniczenie w Mszy św. i w modlitwie wspólnotowej, również za pośrednictwem różnych środków przekazu, będzie dla nich sposobem uzyskania jubileuszowego odpustu" (www 2). Więźniowie z kolei - zgodnie z decyzją papieża, będą mogli uzyskać odpust w kaplicach więziennych, ,a kiedy będą przechodzili przez drzwi swojej celi, kierując myśli i modlitwę do Ojca, niech za każdym razem ten gest oznacza dla nich przejście przez Drzwi Święte, ponieważ miłosierdzie Boże, które potrafi przemienić serca, jest również w stanie przeobrazić kraty w doświadczenie wolności” (www 2).

Uroczysta inauguracja Nadzwyczajnego Jubileuszu Miłosierdzia nastąpiła 8 grudnia 2015 r., kiedy po Mszy św. na Placu św. Piotra w Watykanie, papież Franciszek otworzył Święte Drzwi w Bazylice św. Piotra. Kilka dni później, 12 i 13 grudnia w niemal wszystkich katedrach katolickich oraz w setkach sanktuariów i kościołach na całym świecie zostały otwarte Bramy Miłosierdzia.

Celem prezentowanego opracowania było: ilościowe przedstawienie Bram Miłosierdzia Nadzwyczajnego Jubileuszu Miłosierdzia w Polsce, analiza przestrzennego rozmieszczenia Bram Miłosierdzia w przestrzeni sakralnej Polski, a także 
zgrupowanie Bram Miłosierdzia w odniesieniu do ośrodków pielgrzymkowych w kraju - uwzględniając zasięg przestrzenny oddziaływania, patronat i range sanktuariów. Wykaz wszystkich Bram Miłosierdzia w Polsce opracowano na podstawie Dekretów miejscowych ordynariuszy publikowanych w czasopismach diecezjalnych i zamieszczanych na portalach internetowych diecezji, a także w trakcie rozmów z Kanclerzami Kurii Diecezjalnych lub Metropolitalnych. W przedstawieniu wyników badań posłużono się przede wszystkim metodą dynamiczno-porównawczą, kartograficznymi metodami prezentacji (kartodiagramem i kartogramem) oraz metodami statystycznymi.

\section{Bramy Miłosierdzia w przestrzeni sakralnej Polski}

Zgodnie z postanowieniem papieża Franciszka, w trakcie Nadzwyczajnego Roku Miłosierdzia we wszystkich diecezjach Kościoła katolickiego na świecie otwarto około 10 tys. Drzwi Świętych - Bram Miłosierdzia, w których wierni mogli uzyskać odpust zupełny (www 3). Według Przewodniczącego Papieskiej Rady ds. Krzewienia Nowej Ewangelizacji, ks. Arcybiskupa Rino Fisichella Nadzwyczajny Jubileusz Miłosierdzia był najbardziej zdecentralizowanym w historii Kościoła katolickiego (www 3).

W Polsce, w sumie 669 kościołów lub kaplic zostało przez miejscowych ordynariuszy ogłoszonych Kościołami Jubileuszowymi Roku Miłosierdzia, a w nich otwarto Bramy Miłosierdzia (ryc. 1, tab. 1). W grupie tej znalazły się wszystkie katedry Kościoła katolickiego obrządku łacińskiego (42 katedry, w tym Katedra Polowa Wojska Polskiego Najświętszej Maryi Panny Królowej Polski w Warszawie) oraz 2 katedry Kościoła katolickiego obrządku bizantyjsko-ukraińskiego (Kościół greckokatolicki), a także m.in.: 90 kościołów parafialnych lub filialnych pod wezwaniem Miłosierdzia Bożego, 23 kościoły pod wezwaniem Najświętszego Serca Pana Jezusa, 10 kościołów pod wezwaniem św. Faustyny Kowalskiej, 10 kaplic w szpitalach, 4 kaplice w więzieniach, 2 kaplice klasztorne, 1 kaplica w Domu Hospicyjnym, 1 kaplica Straży Granicznej oraz 1 kaplica w schronisku dla bezdomnych ${ }^{1}$. Należy jednak podkreślić, że liczba Bram Miłosierdzia w kaplicach

1 Opracowany przez Autora wykaz wszystkich Bram Miłosierdzia został zamieszczony na stronie: https://www.researchgate.net/publication/320347454_KOSCIOLY_JUBILEUSZOWE_NADZWYCZAJNEGO_ROKU_MILOSIERDZIA_W_POLSCE. 


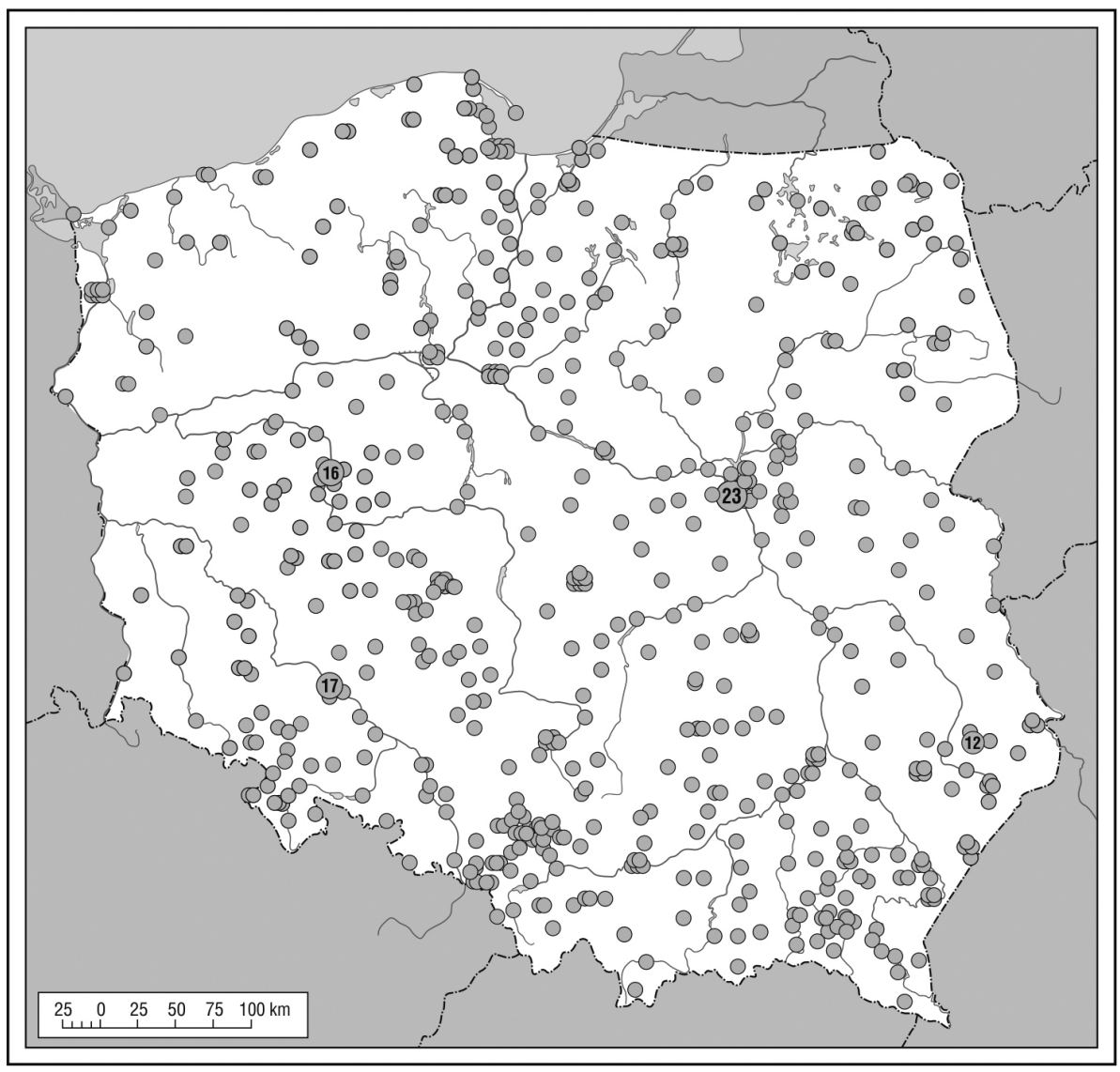

Ryc. 1. Rozmieszczenie Bram Miłosierdzia Nadzwyczajnego Roku Miłosierdzia w Polsce

Źródło: F. Mróz (2016).

szpitalnych, Domach Opieki Społecznej oraz więzieniach była większa od tej, którą biskupi miejsca wykazali w dekretach wskazując dokładny adres placówki. W przypadku bowiem diecezji drohiczyńskiej, zgodnie z dekretem ks. biskupa Tadeusza Pikusa, Bramy Miłosierdzia były ustanowione we wszystkich kaplicach szpitalnych, Domach Opieki Społecznej i więzieniach na terenie danej diecezji dla wszystkich pacjentów i więźniów. W nawiązaniu do bulli papieża Franciszka „Misericordiae Vultus” hierarchowie Kościoła katolickiego w Polsce w swych 


\begin{tabular}{|c|c|c|c|c|c|c|c|c|c|c|c|c|c|c|c|c|c|c|}
\hline \multirow[t]{2}{*}{ 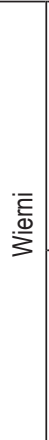 } & 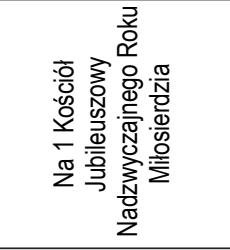 & $\frac{8}{2}$ & $\begin{array}{l}\stackrel{8}{0} \\
\stackrel{0}{\simeq}\end{array}$ & $\begin{array}{l}\hat{8} \\
8 \\
8\end{array}$ & $\frac{m}{\tilde{m}}$ & $\frac{m}{N}$ & $\begin{array}{l}\tilde{m} \\
\infty \\
\tilde{m}\end{array}$ & $\begin{array}{l}\infty \\
\stackrel{2}{ } \\
\text { o } \\
\end{array}$ & $\begin{array}{l}\Re \\
0 \\
\infty \\
\infty \\
i n\end{array}$ & 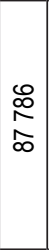 & $\begin{array}{l}\infty \\
\stackrel{\infty}{\infty} \\
\infty\end{array}$ & $\begin{array}{l}\stackrel{?}{\sim} \\
\stackrel{\sim}{N}\end{array}$ & \begin{tabular}{l}
8 \\
8 \\
\multirow{8}{*}{}
\end{tabular} & $\begin{array}{l}\stackrel{\infty}{\sim} \\
\infty \\
i \\
i n\end{array}$ & $\begin{array}{l}\stackrel{2}{+} \\
\stackrel{0}{8}\end{array}$ & $\begin{array}{l}\text { న్ } \\
\text { ్ }\end{array}$ & $\begin{array}{l}\frac{2}{2} \\
\frac{1}{6} \\
\sigma\end{array}$ & 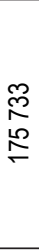 \\
\hline & 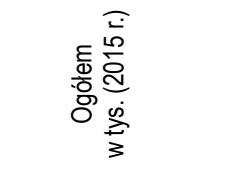 & 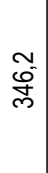 & 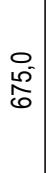 & ㅇ. & 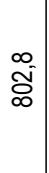 & $\begin{array}{c}\mathfrak{N} \\
\stackrel{\infty}{\infty} \\
\infty\end{array}$ & $\begin{array}{l}\circ \\
\stackrel{9}{+}\end{array}$ & 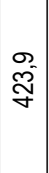 & $\begin{array}{l}0 \\
\infty \\
\infty \\
\tilde{\infty}\end{array}$ & $\frac{n}{ \pm}$ & $\begin{array}{l}n \\
\text { ల్ } \\
\tilde{6}\end{array}$ & $\tilde{\pi}$ & $\begin{array}{l}0 \\
\dddot{m} \\
\infty \\
\end{array}$ & $\begin{array}{l}\infty \\
0 \\
0 \\
\end{array}$ & $\bar{\infty}$ & $\begin{array}{l}\infty \\
\tilde{ల}^{-} \\
{[} \\
{[}\end{array}$ & $\stackrel{\mathscr{N}}{\tilde{N}}$ & 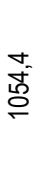 \\
\hline \multirow{6}{*}{ 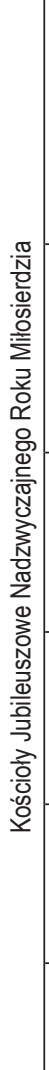 } & 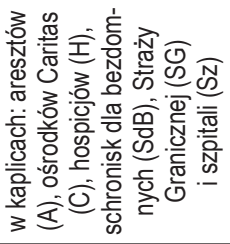 & 1 & 1 & 1 & 1 & 1 & 1 & 1 & $\stackrel{I}{\rightleftharpoons}$ & 1 & 1 & 1 & હે & 1 & 1 & 1 & 1 & 1 \\
\hline & 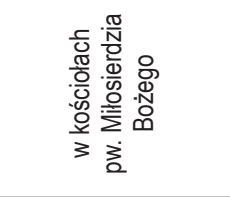 & - & 1 & 1 & $\sim$ & $\sim$ & $\sigma$ & 1 & $m$ & 1 & 1 & $m$ & 0 & $m$ & $\nabla$ & - & 1 & $\sim$ \\
\hline & 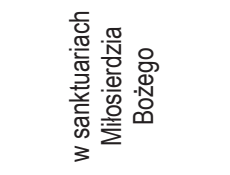 & $\leftarrow$ & 1 & 1 & $\sim$ & $\sim$ & & $\sim$ & $\leftarrow$ & 1 & 1 & $\sim$ & 1 & $\leftarrow$ & 1 & $\leftarrow$ & 1 & 1 \\
\hline & 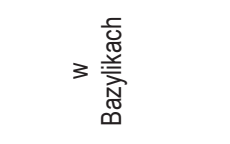 & $\sim$ & & $m$ & $\nabla$ & & & $\sim$ & - & $\leftarrow$ & م & $\sim$ & 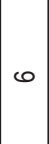 & $\nabla$ & $\leftarrow$ & $\sim$ & م & $m$ \\
\hline & 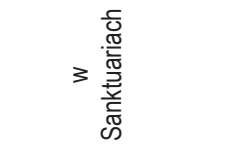 & o & $m$ & 10 & $\mp$ & $\sim$ & $m$ & $\infty$ & $\sim$ & $\sim$ & م & $\oplus$ & $\simeq$ & $\infty$ & $m$ & $\cong$ & $\nabla$ & $\nabla$ \\
\hline & $\frac{E}{\Phi)}$ & 0 & 0 & $\bullet$ & 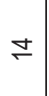 & $m$ & $\cong$ & $\approx$ & $\oplus$ & $\sim$ & $\mp$ & D & I & $\stackrel{m}{\square}$ & $\cong$ & $\stackrel{m}{\rightleftharpoons}$ & $\infty$ & 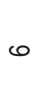 \\
\hline & 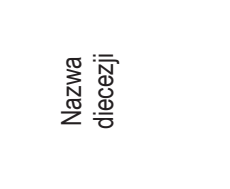 & $\begin{array}{l}\frac{\pi}{0} \\
\frac{0}{00} \\
\frac{0}{\pi} \\
\frac{\pi}{0}\end{array}$ & 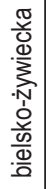 & 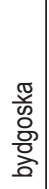 & 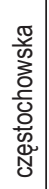 & 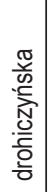 & 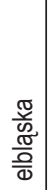 & $\frac{\sqrt{\frac{V}{d}}}{\frac{d}{d}}$ & $\begin{array}{l}\frac{\pi}{w} \\
\frac{\pi}{\pi} \\
\frac{\pi}{8}\end{array}$ & 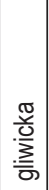 & 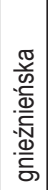 & 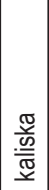 & 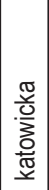 & $\begin{array}{l}\frac{\mathbb{O}}{\mathrm{d}} \\
\frac{\mathbb{d}}{\underline{\underline{W}}}\end{array}$ & 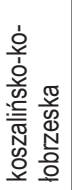 & 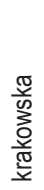 & 总 & 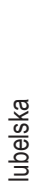 \\
\hline & $\stackrel{\dot{\varphi}}{ }$ & $\dot{-}$ & $\sim$ & $\dot{m}$ & $\dot{\nabla}$ & $10^{\circ}$ & $\omega^{\circ}$ & 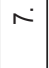 & $\infty$ & $\sigma^{\circ}$ & 음 & $\check{E}$ & $\stackrel{ }{\simeq}$ & $\ddot{m}$ & 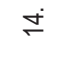 & $\stackrel{\circ}{\circ}$ & $\stackrel{\circ}{\circ}$ & 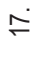 \\
\hline
\end{tabular}




\begin{tabular}{|c|c|c|c|c|c|c|c|c|c|c|c|c|c|c|c|c|c|c|c|c|}
\hline 家 & 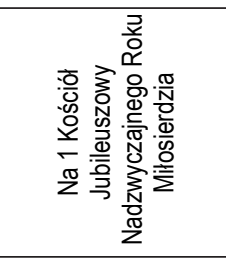 & $\begin{array}{l}2 \\
\infty \\
\infty \\
\stackrel{్}{0}\end{array}$ & $\begin{array}{l}\mathscr{2} \\
\frac{1}{f} \\
8 \\
0\end{array}$ & $\frac{p}{\frac{c}{\sigma}}$ & 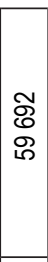 & 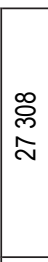 & $\begin{array}{l}\tilde{R} \\
0 \\
0 \\
0 \\
0\end{array}$ & $\begin{array}{l}\text { O } \\
C \\
\text { న }\end{array}$ & $\begin{array}{l}\infty \\
2 \\
2 \\
\text { ని }\end{array}$ & $\begin{array}{l}8 \\
\substack{0 \\
10}\end{array}$ & \begin{tabular}{|l|}
$\hat{o}$ \\
$\tilde{o}$ \\
$\mathscr{m}$
\end{tabular} & $\begin{array}{l}m \\
m \\
\stackrel{m}{q}\end{array}$ & $\begin{array}{l}\mathbb{0} \\
0 \\
\vdots \\
0\end{array}$ & $\begin{array}{l}\text { 员 } \\
\text { a } \\
\text { á }\end{array}$ & 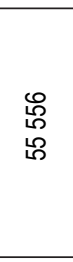 & $\begin{array}{l}\stackrel{\mathbb{R}}{\mathbb{N}} \\
\stackrel{N}{N}\end{array}$ & 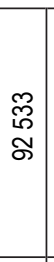 & 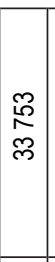 & $\begin{array}{l}\text { 여 } \\
\circ \\
\circ\end{array}$ & 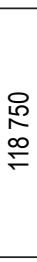 \\
\hline & 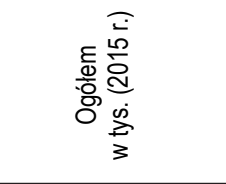 & $\begin{array}{l}0 \\
\infty \\
5 \\
5\end{array}$ & 害 & 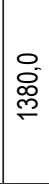 & $\begin{array}{l}0 \\
0 \\
\stackrel{0}{1}\end{array}$ & $\frac{0}{0}$ & $\begin{array}{l}\infty \\
0 \\
0 \\
\infty \\
\infty\end{array}$ & $\begin{array}{l}O \\
\text { O̊ } \\
\stackrel{0}{+}\end{array}$ & 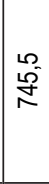 & స్ & జొ & $\begin{array}{l}\hat{\sigma} \\
\hat{\sigma}\end{array}$ & $\begin{array}{l}0 \\
\stackrel{0}{\circ} \\
i\end{array}$ & 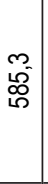 & 응 & 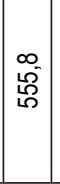 & $\begin{array}{l}\stackrel{+}{O} \\
\stackrel{0}{E}\end{array}$ & $\begin{array}{l}\infty \\
\tilde{N} \\
\tilde{\omega} \\
\tilde{\omega}\end{array}$ & 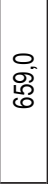 & 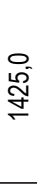 \\
\hline & 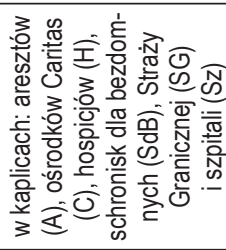 & 1 & 1 & 1 & I & 1 & I & 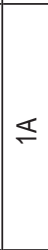 & 1 & 1 & 1 & 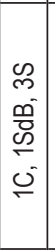 & 1 & 1 & 1 & 1 & 1 & I & 1 & I \\
\hline 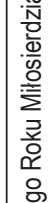 & 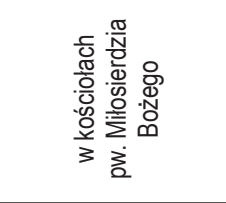 & - & 1 & $\sim$ & $\sim$ & 10 & $m$ & 1 & 0 & 1 & $\sim$ & $\nabla$ & - & & $r$ & - & - & - & $\sim$ & $\forall$ \\
\hline 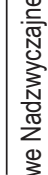 & 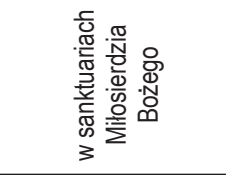 & - & 1 & - & 1 & 1 & - & - & 1 & 1 & 1 & $r$ & - & 1 & $\sim$ & 1 & 1 & - & $\sim$ & - \\
\hline 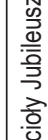 & 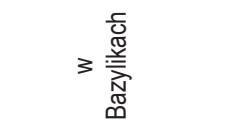 & $\sim$ & - & - & $\sim$ & $m$ & $\sim$ & م & 0 & $\sim$ & $m$ & $\sim$ & m & $m$ & $\sim$ & $m$ & $\infty$ & $\nabla$ & $\infty$ & $\sim$ \\
\hline q & 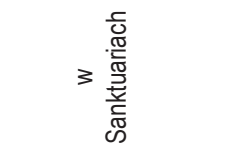 & $E$ & - & $\nabla$ & $m$ & 20 & م & $\stackrel{2}{2}$ & $\mathscr{N}$ & $\infty$ & ( ) & m & $\nabla$ & $\sim$ & $\simeq$ & L & $\infty$ & 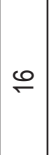 & 0 & ナ \\
\hline & $\frac{\bar{E}}{\frac{\mathrm{o}}{\circ}}$ & $\stackrel{m}{\leftarrow}$ & 0 & $\mp$ & $\stackrel{?}{=}$ & $\stackrel{\sim}{\sim}$ & $\stackrel{20}{\llcorner}$ & 요 & ల్ & $F$ & $\stackrel{2}{2}$ & $\stackrel{20}{\stackrel{2}{2}}$ & $\stackrel{m}{\square}$ & 0 & $\stackrel{\infty}{\leftarrow}$ & $\stackrel{2}{\circ}$ & $\simeq$ & $\neq$ & $\mp$ & $\simeq$ \\
\hline & 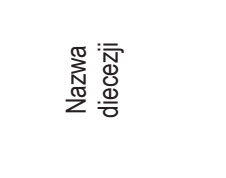 & 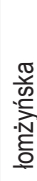 & 용 & $\begin{array}{l}\frac{\mathbb{3}}{N} \\
\frac{N}{0}\end{array}$ & $\begin{array}{l}\frac{\widetilde{T}}{\frac{2}{0}} \\
\frac{0}{0}\end{array}$ & 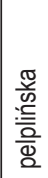 & \begin{tabular}{|l}
$\frac{\pi}{0}$ \\
$\frac{0}{2}$
\end{tabular} & 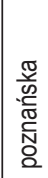 & 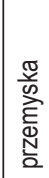 & 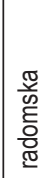 & 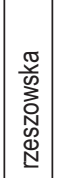 & 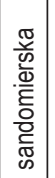 & 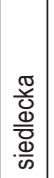 & 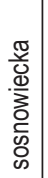 & 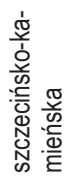 & 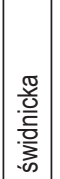 & 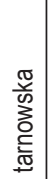 & 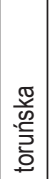 & 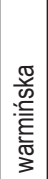 & 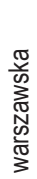 \\
\hline & $\dot{9}$ & $\stackrel{\infty}{\sim}$ & $\stackrel{\circ}{\circ}$ & $\stackrel{\sim}{ }$ & $\dot{\sim}$ & ก & 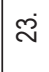 & $\dot{\sim}$ & $\stackrel{2}{2}$ & $\stackrel{\sim}{v}$ & $\grave{\sim}$ & $\stackrel{\sim}{\sim}$ & வ্ं & த் & $\dot{m}$ & లెં & ळ্ল & लें & ம্ల & ச্ं \\
\hline
\end{tabular}




\begin{tabular}{|c|c|c|c|c|c|c|c|c|c|c|}
\hline \multirow[t]{2}{*}{$\begin{array}{l}\overline{\bar{E}} \\
\overline{\underline{\omega}}\end{array}$} & 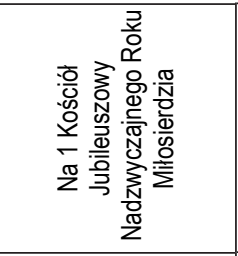 & $\begin{array}{l}\bar{E} \\
0 \\
0\end{array}$ & 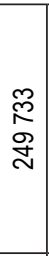 & $\begin{array}{l}\widetilde{\Xi} \\
0 \\
\mathbb{ల}\end{array}$ & 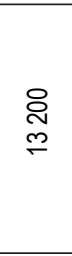 & 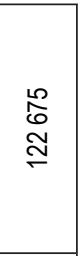 & $\begin{array}{l}\hat{\tilde{D}} \\
\infty \\
\stackrel{F}{F}\end{array}$ & 1 & 1 & 1 \\
\hline & 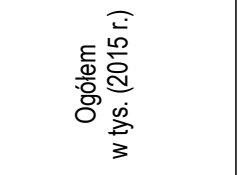 & $\begin{array}{l}\stackrel{+}{0} \\
\text { ŏ } \\
\text { Oे }\end{array}$ & $\begin{array}{c}\stackrel{N}{T} \\
\text { ơ }\end{array}$ & $\begin{array}{l}\hat{N} \\
\stackrel{乛}{=}\end{array}$ & $\begin{array}{l}\text { ్. } \\
\text { ণ্ }\end{array}$ & $\frac{+}{\infty}$ & Оి & 1 & 1 & 1 \\
\hline \multirow{6}{*}{ 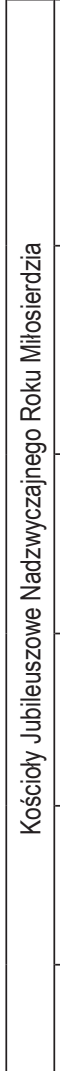 } & 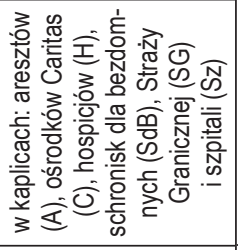 & 1 & 1 & 1 & $\mathscr{0}$ & & 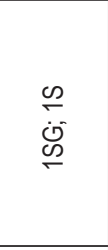 & 1 & 1 & $\stackrel{\infty}{-}$ \\
\hline & 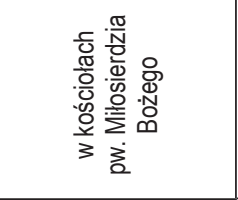 & $\infty$ & 1 & $\sim$ & m & m & $\sim$ & 1 & 1 & 8 \\
\hline & 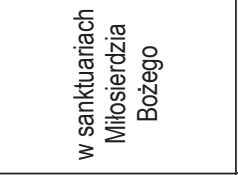 & - & 1 & 1 & 1 & - & 1 & 1 & 1 & $\stackrel{N}{ }$ \\
\hline & 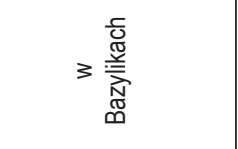 & m & $\sim$ & $\nabla$ & - & - & 1 & 1 & 1 & 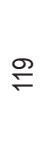 \\
\hline & 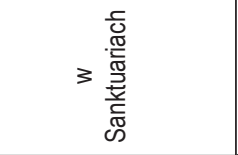 & $\cong$ & $\sim$ & o) & ما & $\nabla$ & 1 & 1 & - & $\bar{m}$ \\
\hline & $\frac{E}{0}$ & $\ddot{m}$ & $m$ & ๗ & 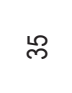 & $\infty$ & $\sim$ & 0 & $\forall$ & ஜ \\
\hline & 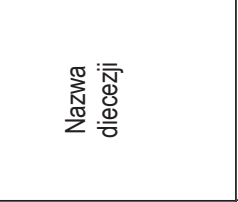 & 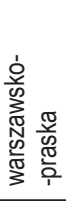 & 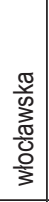 & 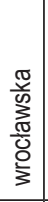 & 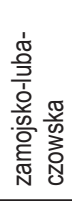 & 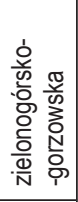 & 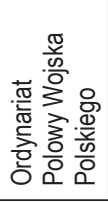 & 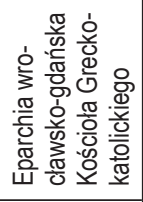 & 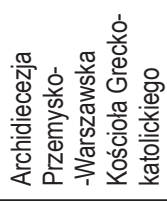 & $\begin{array}{l}\stackrel{0}{5} \\
\stackrel{5}{\oplus}\end{array}$ \\
\hline & $\stackrel{\dot{9}}{ }$ & लें & $\stackrel{\infty}{\circ}$ & ஓं & ơ & $\dot{q}$ & デ & $\ddot{\vartheta}$ & சं & \\
\hline
\end{tabular}

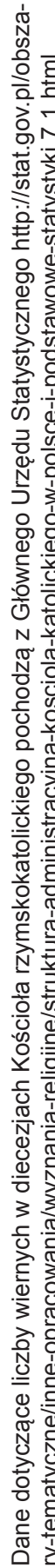


dekretach zaznaczali m.in., że w Jubileuszowym Roku Miłosierdzia, więźniowie mogli uzyskać odpust Jubileuszowy w kaplicach więziennych i „ilekroć przekraczać będą (...) drzwi swojej celi, kierując myśli i modlitwę do Ojca, ten gest oznaczać będzie dla nich przejście przez Drzwi Święte" (Dekret Arcybiskupa Metropolity Białostockiego 2015). Bramy Miłosierdzia zostały otwarte również w 10 cerkwiach Kościoła greckokatolickiego w Polsce - w Przemyślu, Jarosławiu, Warszawie, Olsztynie, Zielonej Górze, Koszalinie, Wrocławiu, Gdańsku, Legnicy i Białym Borze.

Pod względem liczby Bram Miłosierdzia otwartych w trakcie Nadzwyczajnego Jubileuszu Miłosierdzia, Polska była liderem na świecie, wyprzedzając Włochy, gdzie otwarto 639 Świętych Drzwi. Dla porównania w Niemczech otwartych zostały 103 Bramy Miłosierdzia (www 4), na Słowacji - 94 (www 5), w Brazylii - 93 (www 6), w Republice Czeskiej - 42, a na Litwie 15. Określenie dokładnej liczby Bram Miłosierdzia otwartych w Polsce okazało się bardzo utrudnione. W kolejnych bowiem tygodniach Roku Miłosierdzia, biskupi miejsca podpisywali kolejne dekrety bądź aneksy do dekretów ustanawiające nowe Kościoły Jubileuszowe w diecezji. Dla przykładu metropolita krakowski, ks. kardynał Stanisław Dziwisz dwukrotnie podpisał aneksy do „Dekretu o możliwości uzyskania łaski odpustu zupełnego z okazji Nadzwyczajnego Jubileuszu Miłosierdzia w Archidiecezji Krakowskiej", w którym do miejsc świętych wymienionych w tym dekrecie dołączyło sanktuarium Matki Bożej Opiekunki i Królowej Rodzin w Makowie Podhalańskim (4 lutego 2016 r.) i Sanktuarium Diecezjalne św. Jakuba Apostoła w Więcławicach Starych (29 marca 2016 r.). Z kolei w archidiecezji łódzkiej, ks. arcybiskup Marek Jędraszewski dekretem z 25 stycznia 2016 r. ustanowił 5 nowych Bram Miłosierdzia w archidiecezji: kościół pw. Miłosierdzia Bożego w Pabianicach, kościół pw. Świętych Archaniołów Rafała i Michała w Aleksandrowie Łódzkim, kościół pw. Podwyższenia Świętego Krzyża w Brzezinach, kościół pw. Niepokalanego Poczęcia Najświętszej Maryi Panny w Koluszkach oraz kościół pw. Świętego Józefa Oblubieńca Najświętszej Maryi Panny i Podwyższenia Świętego Krzyża w Ozorkowie. Zaledwie kilka dni po rozpoczęciu Roku Miłosierdzia, ks. Arcybiskup Sławoj Leszek Głódź podpisał dekret o otwarciu Bramy Miłosierdzia w franciszkańskim kościele św. Anny i sanktuarium pasyjno-maryjnym w Wejherowie, zaś biskup płocki ks. Piotr Libera dekretem podpisanym w dniu 4 grudnia $2015 \mathrm{r}$. dołączył do grupy 14 Kościołów Jubileuszowych w diecezji płockiej kościół pw. Matki Bożej Różańcowej parafii pw. św. Andrzeja Apostoła w Lubowidzu. W dniu 24 stycznia 2016 r. otwarto Bramę Miłosierdzia w parafii pw. Miłosierdzia Bożego 
w Kraśniku (archidiecezja lubelska), a 6 lutego 2016 r. w sanktuarium Matki Bożej Zawierzenia w Tarnowcu (dekret ks. biskupa Jana Wątroby, ordynariusza rzeszowskiego z dnia 6 lutego 2016 r.) (www 7, Zwiastowanie 2016). Ks. biskup Krzysztof Nitkiewicz, ordynariusz diecezji sandomierskiej, już po rozpoczęciu Roku Miłosierdzia, w kolejnych miesiącach ustanawiał stosownymi dekretami nowe Bramy Miłosierdzia w diecezji: Sanktuarium Relikwii Drzewa Krzyża Świętego na Świętym Krzyżu, Sanktuarium Matki Bożej Bolesnej w Sulisławicach oraz w kościele Źródło Miłosierdzia Bożego w parafii św. Floriana w Stalowej Woli (dekret z dnia 10 lutego 2016 r.) (www 8, www 9), w Szpitalu Specjalistycznym Ducha Świętego w Sandomierzu (7 marca 2016 r.), w kaplicy Caritas w zespole placówek Caritas Diecezji Sandomierskiej w Rudniku nad Sanem (10 marca 2016 r.), oraz w kaplicach szpitalnych w Sandomierzu (Szpital Specjalistyczny Ducha Świętego w Sandomierzu) Tarnobrzegu (Wojewódzki Szpital im. Zofii z Zamoyskich Tarnowskiej w Tarnobrzegu), Staszowie i w kaplicy w sandomierskim schronisku dla bezdomnych (dekret z 23 kwietnia 2016 r.) (Kronika Diecezji Sandomierskiej 2016a, 2016b). W diecezji sandomierskiej liczba Drzwi Miłosierdzia otwartych w Roku Miłosierdzia wzrosła ponad dwukrotnie - z 7 (ustanowionych w dekrecie z 25 października 2016 r.) do 15 (otwartych po 8 grudnia 2015 r.). Warto zaznaczyć, że proces otwierania przez ordynariuszy miejsca kolejnych Bram Miłosierdzia w trwającym Nadzwyczajnym Roku Miłosierdzia nie był tylko precedensem w Polsce. Podobne wydarzenia miały miejsce m.in. w wybranych diecezjach w Czechach i w Niemczech.

W diecezji zamojsko-lubaczowskiej, ks. biskup Marian Rojek dekretem z dnia 30 listopada 2015 r. ustanowił 28 „miejsc jubileuszowych”, w których wierni przez wszystkie dni Roku Miłosierdzia mogli zyskiwać odpusty. W odpowiedzi jednak na prośby duszpasterzy i „kierując się dobrem duchowym diecezjan”, już kilka dni później (7 grudnia 2015 r.) ordynariusz diecezji zamojsko-lubaczowskiej podpisał „Aneks do Dekretu ustanawiającego kościoły jubileuszowe i określającego zasady zyskiwania odpustów z racji Jubileuszowego Roku Miłosierdzia w Diecezji Zamojsko-Lubaczowskiej" w którym dołączył do wcześniej ustanowionych kościołów jubileuszowych w diecezji 7 kościołów parafialnych: kościół pw. Matki Bożej Nieustającej Pomocy w Aleksandrowie, kościół pw. Trójcy Świętej i Wniebowzięcia NMP w Biłgoraju, kościół pw. Miłosierdzia Bożego w Harasiukach, kościół pw. Podwyższenia Krzyża Świętego w Horyszowie Polskim, kościół pw. Matki Bożej Nieustającej Pomocy w Hrubieszowie, kościół pw. Narodzenia NMP w Narolu oraz kościół pw. Św. Katarzyny Aleksandryjskiej w Szczebrzeszynie 
(Zamojski Informator Diecezjalny 2015: 671). Również metropolita przemyski, ks. Arcybiskup Józef Michalik dekretem z 25 stycznia 2016 r. ustanowił kolejne Bramy Miłosierdzia w archidiecezji przemyskiej - w kościołach parafialnych i filialnych pw. Miłosierdzia Bożego w archidiecezji przemyskiej (Jarosław, Krosno, Przemyśl - Rycerskie, Skołoszów, Turze Pole, Wetlina, Wola Komborska, Dębna i Glinne). Nowa Brama Miłosierdzia w diecezji toruńskiej została otwarta 18 maja 2016 r. przez ks. kard. Zenona Grocholewskiego - prefekta-seniora Kongregacji Edukacji Katolickiej w trakcie konsekracji sanktuarium Najświętszej Maryi Panny Gwiazdy Nowej Ewangelizacji i św. Jana Pawła II w Toruniu.

Niestety również zapisy księży biskupów w dekretach ustanawiających Bramy Miłosierdzia sprawiały trudność w dokładnym określeniu liczby Bram na terenie diecezji. Przykładem może być dekret ks. biskupa Andrzeja Suskiego, ordynariusza diecezji toruńskiej, w którym czytamy „W tych miastach diecezji toruńskiej, gdzie brak sanktuarium, wyznaczam na kościół z Bramą Miłosierdzia najstarszą świątynię parafialną" (www 10).

Na podkreślenie zasługują także Bramy Miłosierdzia otwarte „czasowo”. Do takich Świętych Drzwi należały: Brama Ryba na Polach Lednickich, która była Bramą Miłosierdzia decyzją Prymasa Polski, ks. Arcybiskupa Wojciecha Polaka podczas XX Spotkania Młodych w dniu 4 czerwca 2016 r.; Brama Miłosierdzia otwarta w kościele przyseminaryjnym podczas dnia otwartego Wyższego Międzydiecezjalnego Seminarium Duchownego w Opolu (tylko 30 kwietnia 2016 r.) oraz kościół parafialny pw. Matki Bożej Niepokalanej w Desznicy popularnej miejscowości wypoczynkowej w Beskidzie Niskim, który dekretem ks. Biskupa Jana Wątroby, ordynariusza rzeszowskiego był Kościołem Stacyjnym Roku Miłosierdzia w okresie wakacyjnym 2016 r. (od 29 czerwca do 26 sierpnia 2016 r.) (www 11, www 12). Wyjątkowe znaczenie miała Brama Miłosierdzia postawiona na Campusie Misericordia w Brzegach w trakcie 31. Światowych Dni Młodzieży "Kraków 2016". Przez tą Bramę, 30 lipca 2016 r. przeszedł Papież Franciszek rozpoczynając czuwanie modlitewne z 2,5 milionową rzeszą młodzieży z 187 krajów świata (www 13, www 14). Bramę zbudowali górale z drewnianych listew, a w jej zwieńczeniu umieszczono kopię obrazu Pana Jezusa Miłosiernego z sanktuarium Bożego Miłosierdzia w Krakowie-Łagiewnikach². Bramy Miłosierdzia zostały otwarte w 119 bazylikach mniejszych (tj. 85\% ogółu bazylik mniejszych w Polsce).

2 Obecnie ta Brama Miłosierdzia znajduje się w Świątyni Opatrzności Bożej w Warszawie. 
Najwięcej Bram Miłosierdzia otwarto w archidiecezji poznańskiej (50 ośrodków), w archidiecezji przemyskiej (36), w diecezji warszawsko-praskiej (36), w diecezji zamojsko-lubaczowskiej (35), w diecezji kaliskiej (29) oraz w archidiecezji katowickiej (29) (ryc. 2). Z kolei tylko trzy Bramy Miłosierdzia wierni mogli przekroczyć w diecezji drohiczyńskiej oraz włocławskiej, zaś po 6 w archidiecezji białostockiej i lubelskiej, oraz w diecezjach: bielsko-żywieckiej, bydgoskiej, łowickiej i sosnowieckiej. Liczba wiernych przypadająca na 1 Bramę Miłosierdzia była największa w diecezji włocławskiej (249,7 tys.), w archidiecezji lubelskiej (175,7 tys.), w diecezji zielonogórsko-gorzowskiej (122,7 tys.), w archidiecezji krakowskiej (120,2 tys.), w archidiecezji warszawskiej (118,7 tys.) oraz diecezji bielsko-żywieckiej (112,5 tys.), zaś najmniejsza w diecezji zamojsko-lubaczowskiej (13,2 tys.), ełckiej (19,3 tys.), przemyskiej (20,7 tys.) i kaliskiej (25,2 tys.) (ryc. 3). W wielu diecezjach, w wyborze lokalizacji Bram Miłosierdzia kierowano się przede wszystkim ich dostępnością dla jak największej liczby wiernych. Stąd kościoły jubileuszowe zostały ustanowione w największych miastach diecezji oraz poszczególnych rejonach duszpasterskich. Wśród miast, najwięcej Bram Miłosierdzia zostało otwartych w Warszawie (23), Wrocławiu (16), Poznaniu (17), Zamościu (12), Gdańsku (7), Katowicach (6), Łodzi (6) i w Toruniu (6). W dekretach ustanawiających Kościoły Jubileuszowe biskupi życzyli kapłanom posługującym w tych miejscach, a zwłaszcza spowiednikom i wiernym nawiedzającym te świątynie, autentycznego doświadczenia Miłosierdzia Bożego i udzielali pasterskiego błogosławieństwa.

\section{Bramy Miłosierdzia w sieci ośrodków pielgrzymkowych Polski}

W Polsce rejestruje się blisko 800 sanktuariów i miejsc szczególnego związanych przede wszystkim z Kościołem rzymskokatolickim. Wśród nich zdecydowanie dominują sanktuaria maryjne (około 70\% ogółu). Pozostałe sanktuaria to sanktuaria Pańskie (ponad 100 ośrodków) oraz sanktuaria świętych i błogosławionych (ponad 150 ośrodków) (Mróz 2016). W trakcie Nadzwyczajnego Jubileuszu Miłosierdzia, zgodnie z dekretami ordynariuszy miejsca, w 311 sanktuariach otwarte były Bramy Miłosierdzia (ryc. 4).

Uwzględniając przyjętą w literaturze przedmiotu typologię sanktuariów ze względu na zasięg przestrzenny oddziaływania, należy stwierdzić, że Bramy Miłosierdzia otwarte były w niemal wszystkich sanktuariach o randze międzynarodowej 

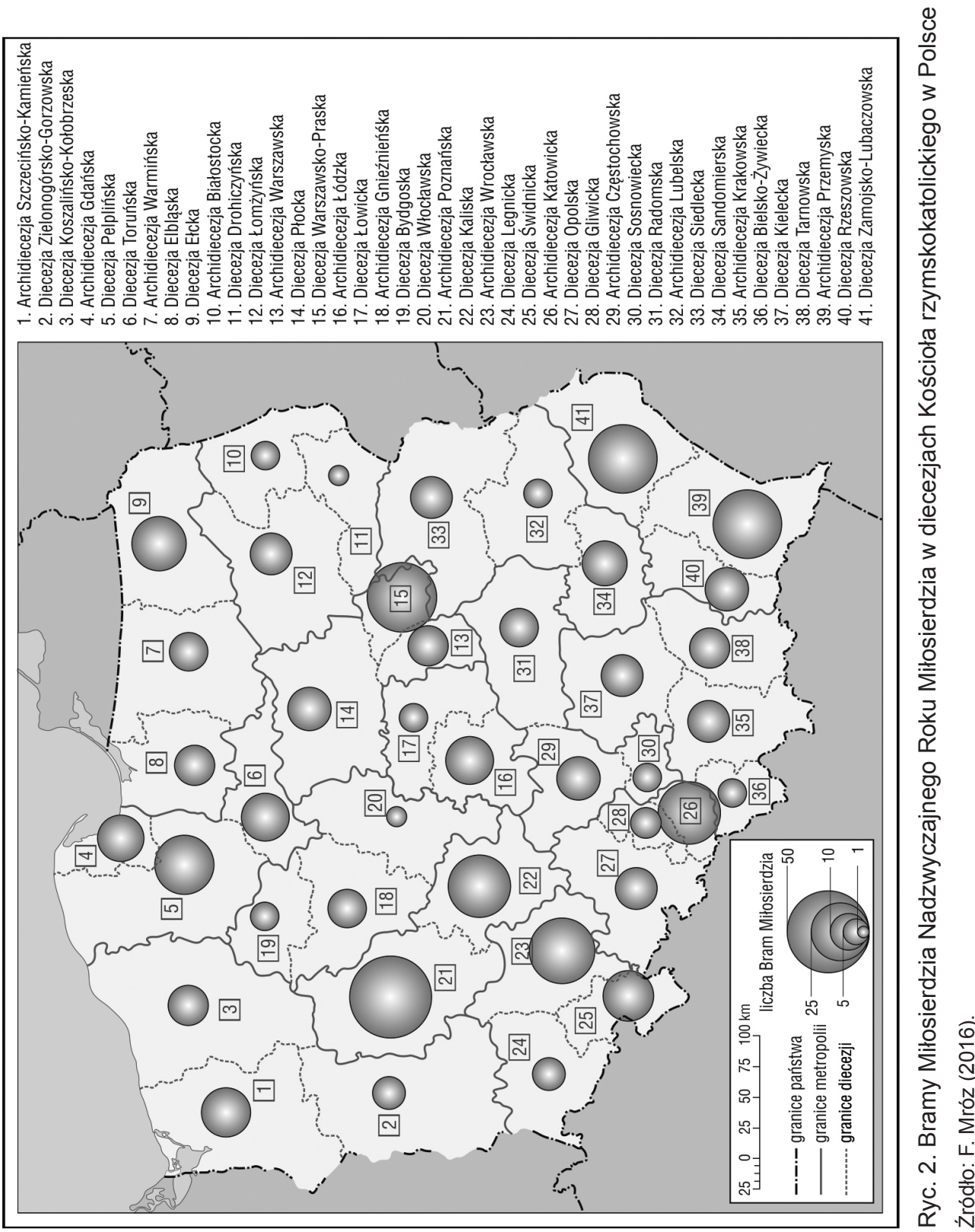


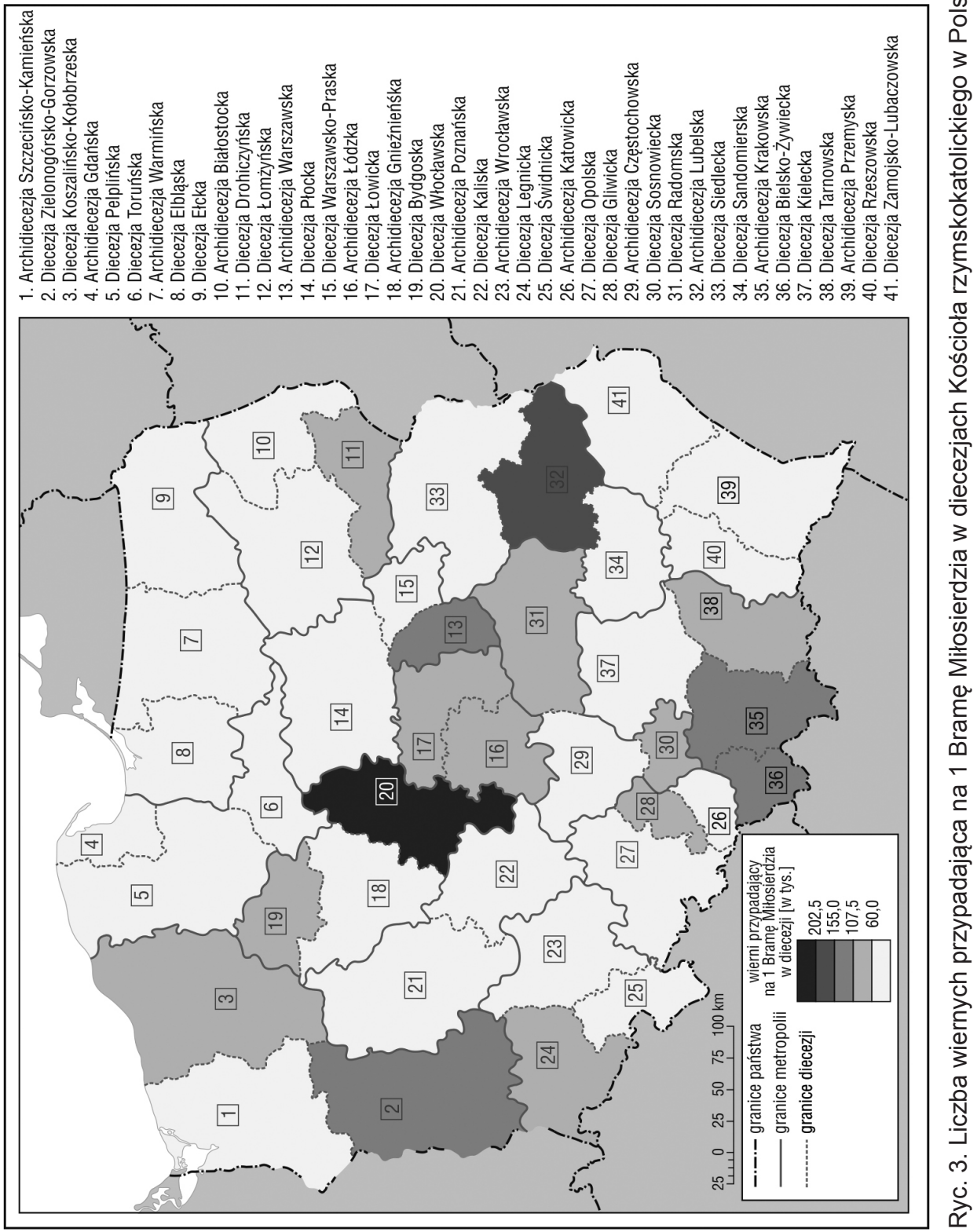

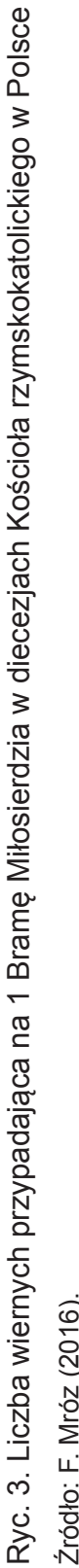




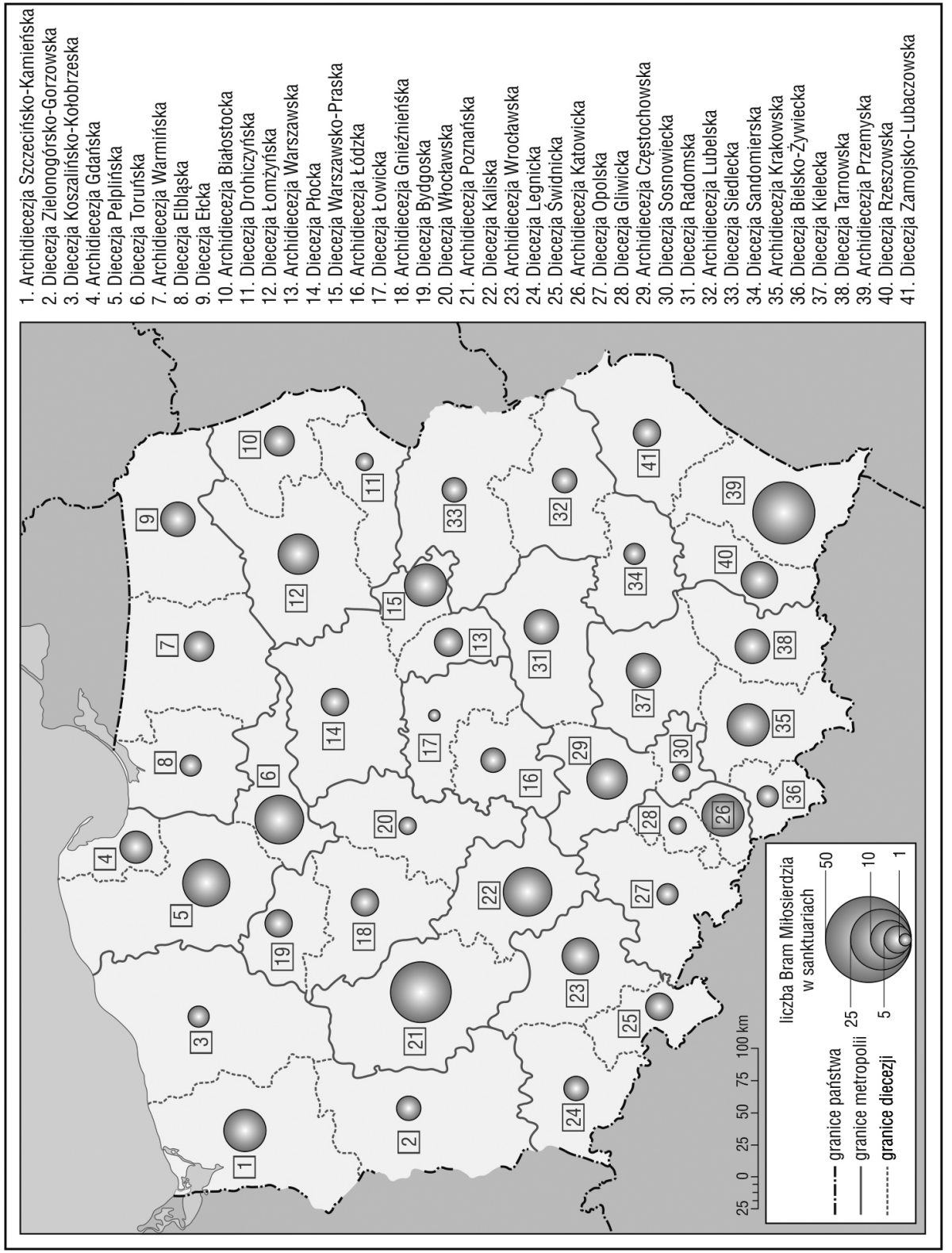

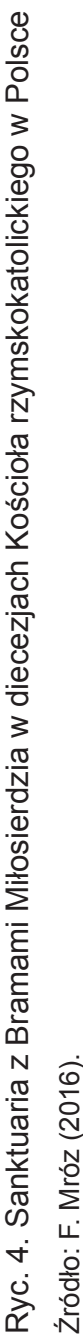


(za wyjątkiem Sanktuarium Matki Bożej Fatimskiej w Zakopanem-Krzeptówkach) tj.: w sanktuarium Matki Bożej Częstochowskiej na Jasnej Górze, sanktuarium Bożego Miłosierdzia w Krakowie-Łagiewnikach, sanktuarium św. Jana Pawła II w Krakowie, sanktuarium Męki Pańskiej i Matki Bożej Kalwaryjskiej w Kalwarii Zebrzydowskiej, Sanktuarium Matki Bożej Niepokalanej i św. Maksymiliana Kolbego w Niepokalanowie, sanktuarium św. Anny na Górze Świętej Anny, sanktuarium bł. Ks. Jerzego Popiełuszki w Warszawie, sanktuarium Matki Bożej Bolesnej Królowej Polski w Licheniu oraz w mieście urodzin św. Jana Pawła II Bazylice Ofiarowania Najświętszej Maryi Panny w Wadowicach i w kościele parafialnym pw. św. Piotra (sanktuarium Matki Bożej Fatimskiej). Warto podkreślić, że przez Bramę Miłosierdzia w sanktuarium Bożego Miłosierdzia w Krakowie oraz Bramę Miłosierdzia w sanktuarium św. Jana Pawła II na Białych Morzach w Krakowie przeszedł papież Franciszek w trakcie swej pielgrzymki do Polski (30 lipca 2016 r.).

Również we wszystkich sanktuariach o randze krajowej (sanktuarium Relikwii Drzewa Krzyża Św. na Świętym Krzyżu, sanktuarium św. Wojciecha w Gnieźnie i sanktuarium Matki Bożej Piekarskiej w Piekarach Śląskich) otwarte były Bramy Miłosierdzia. Bramą Miłosierdzia w katedrze św. Wojciecha w Gnieźnie były XII-wieczne Drzwi Gnieźnieńskie, a otworzył je Prymas Polski, ks. abp Wojciech Polak. Była to najstarsza w Polsce Brama Miłosierdzia. Nieco zaskakujący może być fakt, że Święte Drzwi w sanktuarium Relikwii Drzewa Krzyża Świętego zostały otwarte nie na inaugurację Roku Miłosierdzia w diecezji sandomierskiej, ale dopiero 21 lutego $2016 \mathrm{r}$.

Do grupy sanktuariów o randze ponaddiecezjalnej w Polsce zalicza się ponad 50 sanktuariów (Mróz 2016). W tej grupie Bramy Miłosierdzia otwarte były w 44 ośrodkach, a więc w: Bardzie Śląskim, Białymstoku (sanktuarium Miłosierdzia Bożego), Borku Wielkopolskim, na Chełmskiej Górze, Częstochowie (Dolina Miłosierdzia), Dębowcu, Dukli, Gidlach, Gietrzwałdzie, Gostyniu - Świętej Górze, Górce Duchownej, Górce Klasztornej, Kaliszu (sanktuarium św. Józefa), KałkowieGodowie, Kodniu, Krasnobrodzie, Krzeszowie, Leśnej Podlaskiej, Leśniowie, Leżajsku, Ludźmierzu, Kalwarii Pacławskiej, Krakowie-Mogile, Myśliborzu, Oborach, Pakości, Płocku, Pszowie, Rokitnie, Różanymstoku, Rywałdzie Królewskim, Sianowie, Skępem, Skrzatuszu, Sokółce, Studzienicznej, Swarzewie, Stoczku Klasztornym, Świętej Lipce, Trzebnicy, Tuchowie, Wambierzycach, Wąwolnicy i Wejherowie. 
Najliczniejszą grupę sanktuariów w których otwarte były Święte Drzwi Nadzwyczajnego Roku Miłosierdzia stanowiły sanktuaria o randze lokalnej i diecezjalnej.

Grupując sanktuaria z Bramami Miłosierdzia ze względu na przedmiot kultu, najbardziej liczną grupę stanowity sanktuaria maryjne. W 2016 r. w Polsce funkcjonowało ponad 500 sanktuariów maryjnych, a wśród nich Bramy Miłosierdzia otwarte były w 199 ośrodkach. W zdecydowanej większości były to sanktuaria maryjne $z$ wizerunkami Matki Bożej koronowanymi na prawie papieskim osobiście przez papieża lub „w imieniu i powagą papieża”, po otrzymaniu stosownego zezwolenia od Kongregacji Kultu Bożego Stolicy Świętej (Mróz F., Mróz Ł. 2012). Na szczególne podkreślenie w tej grupie zasługuje główne sanktuarium Kościoła greckokatolickiego w Polsce, a więc cerkiew pw. Przemieniania Pańskiego w Jarosławiu. Cudowna ikona Matki Bożej nazywana „Bramą Miłosierdzia” czczona w tym sanktuarium, została na specjalne życzenie papieża Franciszka przewieziona do Watykanu i wystawiona na ołtarzu głównym podczas inauguracji Nadzwyczajnego Jubileuszu Miłosierdzia na Placu św. Piotra w dniu 8 grudnia 2015 r.

Bramy Miłosierdzia zostały otwarte w 58 sanktuariach Pańskich w Polsce, z czego aż w 26 sanktuariach Miłosierdzia Bożego (Białymstoku, Białej Podlaskiej, Bielsku Podlaskim, Częstochowie, Ełku, Gdańsku-Wrzeszczu, Kaliszu, Kielcach, Krakowie-Łagiewnikach, Łodzi, Łomży, Myśliborzu, Olsztynie na Nagórkach, Olsztynie-Zatorzu, Ostrowcu Świętokrzyskim, Ostrowie Wielkopolskim, Ożarowie Mazowieckim, Płocku, Poznaniu, Sokołowie Podlaskim, Suwałkach, Szczecinie, Świebodzinie, Toruniu, Warszawie oraz w Zawierciu-Blanowicach). Jedynymi sanktuariami Bożego Miłosierdzia w Polsce, w których nie otwarto Bramy Miłosierdzia były sanktuaria w Sosnowcu i Świdnicy. Wyjątkowe znaczenie miały uroczystości zamknięcia Nadzwyczajnego Roku Miłosierdzia w diecezji drohiczyńskiej, które odbyły się w kościele Bożego Miłosierdzia w Bielsku Podlaskim w dniu 13 listopada 2016 r. W ich trakcie ks. biskup Tadeusz Pikus, ordynariusz diecezji drohiczyńskiej ogłosił dekret ustanawiający świątynię Diecezjalnym Sanktuarium Bożego Miłosierdzia (www 15).

W grupie sanktuariów świętych i błogosławionych, których obecnie w Polsce rejestruje się ponad 150, Bramy Jubileuszu Miłosierdzia otwarto w 53 sanktuariach. W grupie tej najważniejszą rangą odznaczały się wspomniane już sanktuaria w Niepokalanowie (sanktuarium św. Maksymiliana Marii Kolbego), na Białych Morzach w Krakowie (sanktuarium św. Jana Pawła II), 
w Warszawie (sanktuarium bł. Ks. Jerzego Popiełuszki w Warszawie) i na Górze Świętej Anny (sanktuarium św. Anny). Warto podkreślić również, że Bramy Miłosierdzia otwarte zostały w sanktuariach związanych z kultem Apostołki Bożego Miłosierdzia, tj. w Sanktuarium Urodzin i Chrztu św. Siostry Faustyny Kowalskiej w Świnicach Warckich oraz w sanktuarium św. Faustyny w Kiekrzu (do ośrodków kultu św. Faustyny zaliczyć należy oczywiście m.in. sanktuarium Miłosierdzia Bożego w Krakowie-Łagiewnikach oraz sanktuarium Miłosierdzia Bożego w Płocku).

Bramy Miłosierdzia zostały otwarte również w 6 sanktuariach pasyjno-maryjnych, tj. w Kalwarii Pacławskiej, Kalwarii Zebrzydowskiej, Pakości, Wambierzycach, Wejherowie, oraz w Wielu.

Zdecydowana większość (77\%) sanktuariów w których znajdowały się Bramy Miłosierdzia była pod patronatem kleru diecezjalnego. 73 sanktuariów w których otwarto Święte Drzwi Nadzwyczajnego Jubileuszu Miłosierdzia jest pod opieką zgromadzeń zakonnych, przy czym w większości tych ośrodków pracują zakonnicy (www 16).

\section{Zakończenie}

Nadzwyczajny Jubileusz Miłosierdzia był szczególnym czasem łaski i odnowy duchowej wiernych Kościoła katolickiego na świecie. W Nadzwyczajnym Roku Świętym ożywił i rozwinął się ruch pątniczy do setek katedr, świątyń i sanktuariów, w których znajdowały się Bramy Miłosierdzia. Papież Franciszek w bulli Misericordiae Vultus podkreślił: „Są chwile, w których jeszcze mocniej jesteśmy wzywani, aby utkwić wzrok w miłosierdziu, byśmy sami stali się skutecznym znakiem działania Ojca. Z tego właśnie powodu ogłosiłem Nadzwyczajny Jubileusz Miłosierdzia jako pełen łaski czas dla Kościoła, by uczynić świadectwo wierzacych jeszcze mocniejszym i skuteczniejszym”. Poza Rzymem, w którym odbywały się główne uroczystości Roku Miłosierdzia, uwage milionów chrześcijan na świecie skupiły Światowe Dni Młodzieży, które odbyły się w dniach od 26 do 31 lipca 2017 r. w Krakowie - w światowej stolicy Bożego Miłosierdzia. To niezapomniane święto młodych z udziałem papieża Franciszka odbyło się pod hasłem „Błogosławieni miłosierni, albowiem oni miłosierdzia dostąpią. Po raz kolejny, sanktuarium Bożego Miłosierdzia w Krakowie-Łagiewnikach było w centrum wydarzeń Kościoła katolickiego na świecie. Przeprowadzone przez Autora badania 
ruchu pielgrzymkowego w części sanktuariów o randze co najmniej ponaddiecezjalnej wykazały, że w Nadzwyczajnym Jubileuszu Miłosierdzia ruch pątniczy był wyraźnie większy niż w latach wcześniejszych. Pełna analiza tego zjawiska wymaga jednak odrębnego opracowania.

\section{Literatura}

Dekret Arcybiskupa Metropolity Białostockiego w związku z ogłoszeniem Nadzwyczajnego Jubileuszu Miłosierdzia, „Wiadomości Kościelne Archidiecezji Białostockiej”, nr 4, 2015, s. 164; http://www.parafia.swidwin.pl/images/dekret_jubileuszowy.pdf (dostęp: 20.09.2016).

„Kwartalnik Diecezjalny. Pismo urzędowe Diecezji Bielsko-Żywieckiej”, 2015, nr IV, Bielsko Biała.

„Kronika Diecezji Sandomierskiej”, Wydawnictwo Diecezjalne w Sandomierzu, 2016a, nr 3-4.

„Kronika Diecezji Sandomierskiej”, Wydawnictwo Diecezjalne w Sandomierzu, 2016b, nr 11-12.

„Kronika Archidiecezji Przemyskiej”, 2015, nr 100, Wydawnictwo Archidiecezji Przemyskiej, Przemyśl.

„Kronika Archidiecezji Przemyskiej”, 2016, nr 101, Wydawnictwo Archidiecezji Przemyskiej, Przemyśl.

„Memoranda. Wiadomości Archidiecezji Lubelskiej”, nr 4 (2015), Kuria Metropolitalna w Lublinie, s. 708-709.

„Miesięcznik Archidiecezji Gdańskiej”, 2016, 60, 1-3, Kuria Metropolitalna Gdańska, s. 121-122.

Mróz F., 2016, Sanktuaria Kościoła Rzymskokatolickiego w przestrzeni sakralnej Polski, [w:] J. Latosińska, J. Mokras-Grabowska (red.), Kultura i turystyka. Sacrum i profanum, Regionalna Organizacja Turystyczna Województwa Łódzkiego, Łódź. s. $183-205$.

Mróz F., Mróz Ł., 2012, Koronacje papieskie (na mocy dekretu Stolicy Apostolskiej) wizerunków Najświętszej Maryi Panny w Polsce w latach 1990-2011, „Peregrinus Cracoviensis", 23, s. 31-50.

„Notificationes e Curia Metropolitana Cracoviensi”, 2015, 153, nr 10-12, Kuria Metropolitalna w Krakowie, s. 98-100.

„Świdnickie Wiadomości Kościelne”, 2015, nr 4 (48), Świdnicka Kuria Biskupia, s. 131-133. 
„Toruńskie Wiadomości Kościelne”, 2015, nr 3-4 (95-95), Kuria Diecezjalna w Toruniu, s. 67-68.

„Wiadomości Kościelne Archidiecezji Białostockiej”, 2015, nr 4, 2015, Kuria Biskupia w Białymstoku.

„Wrocławskie Wiadomości Kościelne. Pismo urzędowe Wrocławskiej Kurii Metropolitalnej”, 2015, 68, nr 2 , s. 148-151.

„Zamojski Informator Diecezjalny”, 2015, 24, nr 4, Wydawnictwo Kurii Diecezjalnej w Zamościu, Zamość, s. 668-671.

„Zwiastowanie. Pismo Diecezji Rzeszowskiej, 2015, 24, nr 4, Kuria Diecezjalna w Rzeszowie.

„Zwiastowanie. Pismo Diecezji Rzeszowskiej, 2016, 25, nr 2, Kuria Diecezjalna w Rzeszowie.

\section{Strony internetowe}

www 1: http://www.w2.vatican.va/content/francesco/pl/bulls/documents/papa-francesco_bolla_20150411_misericordiae-vultus.html (pozyskano 15.02.2016).

www 2: http://www.iubilaeummisericordiae.va/content/gdm/pl/giubileo/lettera.html (pozyskano 15.02.2016).

www 3: http://www.radiovaticana.va/proxy/pol_RG/2015/Dicembre/15_12_14.

html\#Art_1194319 (pozyskano 15.02.2016).

www 4: http://www.dbk.de/heiliges-jahr/das-heilige-jahr-in-den-bistuemern/heilige-pforten/ (dostęp: 10.12.2016)

www 5: http://www.kbs.sk/pdf/TEMP/miscordiagate2016.pdf (dostęp: 20.12.2016). www 6: https://noticias.cancaonova.com/brasil/porta-do-ano-da-misericordia-seraaberta-em-todas-as-dioceses-do-brasil-veja-mapa/ (dostęp: 20.12.2016).

www 7: http://www.sanktuariumtarnowiec. parafia.info.pl/?p=main\&what $=127$ (dostęp: 14.04.2016).

www 8: http://www.diecezjasandomierska.pl/diecezjalne/1985-nowe-,drzwi-święte”w-diecezji-sandomierskiej.html (dostęp: 20.09.2016).

www 9: http://www.swietykrzyz.pl/aktualnosci_span/1138/dekret (dostęp:

20.09.2016).

www 10: https://diecezja-torun.pl/Artykuly/View/800/dekret-bpa-andrzeja-suskiego-na-rok-milosierdzia (dostęp: 15.02.2016).

www 11: https://system.ekai.pl/kair/?screen=depesza\&_scr_depesza_id_depe-

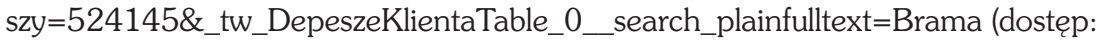
20.09.2016). 
www 12: http://www.diecezja.rzeszow.pl/2016/06/komunikaty-kurii-xiii-niedziela-zwykla-26-06-2016-r/ (dostęp: 15.12.2016).

www 13: http://www.kosciol.wiara.pl/doc/3318774.SDM-Odrobina-statystyk (dostęp: 20.09.2016).

www 14: http://www.krakow2016.com/bp-damian-muskus-koordynator-generalnysdm-3-miliony-pielgrzymow-uczestniczylo-we-mszy-poslania-na-campus-misericordia; (dostęp: 15.12.2016).

www 15: http://www.drohiczynska.pl/aktualnosci/sanktuarium-milosierdzia-bozegow-bielsku-podlaskim (dostęp: 12.12.2016).

www 16: http://www.zyciezakonne.pl/informator/sanktuaria-zakonne (dostęp:

15.12.2016).

http://archibial.pl/nadzwyczajny_jubileusz_milosierdzia.php?id=6 (dostęp: 20.09.2016) http://diecezja.bielsko.pl/wydarzenia/koscioly-jubileuszowe-nadzwyczajny-jubileuszmilosierdzia/ (dostęp: 20.09.2016).

http://parafiabogdanow.manifo.com/warto-przeczytac/koscioly-jubileuszowe-warchidiecezji-czestochowskiej-w-roku-swietym-milosierdzia (dostęp: 20.09.2016). http://drohiczynska.pl/dekrety/ (dostęp: 20.09.2016).

http://diecezja.elblag.pl/home/show/jubileusz-miosierdzia-kocioy-odpustu-zupenegodiecezji-elblaskiej/ (dostęp: 20.09.2016).

http://www.jubileusz.diecezja.elk.pl/ (dostęp: 20.09.2016).

http://www.diecezja.gda.pl/nowosci/2536-koscioly-jubileuszowe-archidiecezjigdanskiej (dostęp: 20.09.2016).

http://www.kuria.gliwice.pl/index.php?option=com_content\&view=article\&id=4572: dekret-rok-milosierdzia-2016\&catid=80\&Itemid=201 (dostęp: 20.09.2016).

http://www.archidiecezja.pl/duszpasterstwo/rok_milosierdzia/bramy_milosierdzia_. html (dostęp: 20.09.2016).

http://diecezja.kalisz.pl/articles/DEKRET_BP_KAL_UST_KRJ_2015-1.pdf (dostęp: 20.09.2016).

http://katowice.gosc.pl/doc/2856656.Odpusty-w-Roku-Milosierdzia (dostęp: 20.09.2016).

http://www.diecezja.kielce.pl/bp-jan-piotrowski-wyznaczyl-koscioly-jubileuszowe-narok-milosierdzia (dostęp: 20.09.2016).

http://niedziela.pl/artykul/19620/Bramy-Milosierdzia-w-diecezji (dostęp: 20.09.2016). http://legnica.gosc.pl/gal/spis/3540694.Bramy-Milosierdzia-diecezji-legnickiej (dostęp: 20.09.2016). 
http://archidiecezjalubelska.pl/blog/bramy-milosierdzia-w-kosciolach-jubileuszowychzostaly-otwarte/ (dostęp: 20.09.2016).

http://www.diecezja.lomza.pl/kuria/komunikaty-kurii/item/946-koscioly-stacyjne-jubileuszu-milosierdzia \(dostęp: 20.09.2016).

http://www.diecezja.lowicz.pl/serwis/index.php?id=805\&idd=1611 (dostęp:

20.09.2016).

http://archidiecezja.lodz.pl/new/?news_id=4b2e804947a7f5bb9dbba24adcc3f241

(dostęp: 20.09.2016).

http://www.diecezja.opole.pl/ (dostęp: 12.12.2016).

http://niedziela.pl/artykul/19628/Koscioly-jubileuszowe-diecezji (dostęp: 20.09.2016). http://diecezjaplocka.pl/dla-ksiezy/panel-ksiedza/dekrety/dekret-biskupa-plockiego-ustanawiajacy-swiatynie-jubileuszowe-w-roku-nadzwyczajnego-jubileuszu-milosierdzia (dostęp: 20.09.2016).

http://niedziela.pl/artykul/19551/Bramy-Milosierdzia-w-archidiecezji (dostęp:

12.12.2016).

http://www.diecezja.rzeszow.pl/2015/11/dekret-ustanawiajacy-koscioly-stacyjne-najubileusz-milosierdzia/ (dostęp: 12.12.2016).

http://www.diecezjasandomierska.pl/diecezjalne/1985-nowe-,„drzwi-święte”-wdiecezji-sandomierskiej.html (dostęp: 12.12.2016).

http://www.diecezjasandomierska.pl/sandomierskie/2005-sulisławskie-podwoje-łaski.htm (dostęp: 20.09.2016).

http://niedziela.pl/artykul/19615/Bramy-Milosierdzia-w-diecezji-siedleckiej (dostęp: 20.09.2016).

http://www.diecezja.sosnowiec.pl/aktualnosci/4047-koscioly-z-brama-milosierdzia-dekret-biskupa (dostęp: 20.09.2016).

http://szczecin.kuria.pl/aktualnosci/Dekret-Ksiedza-Arcybiskupa-Metropolity-na-Rok-Milosierdzia_2762 (dostęp: 12.12.2016).

http://www.diecezja.swidnica.pl/index.php/dokumenty/1967-deret-biskupa-swidnickiego-dotyczacy-odpustow-w-roku-swietym-milosierdzia-na-terenie-diecezji-swidnickiej (dostęp: 12.12.2016).

http://www.diecezja.tarnow.pl/index.php/wiadomosci/item/3084-dwanascie-bram-milosierdzia (dostęp: 20.09.2016).

https://diecezja-torun.pl/Artykuly/View/800/dekret-bpa-andrzeja-suskiego-na-rok-milosierdzia (dostęp: 20.09.2016).

http://archwwa.pl/aktualnosci/koscioly-jubileuszowe-w-archidiecezji-warszawskiej/ (dostęp: 20.09.2016). 
http://pomocnicy.waw.pl/rok-milosierdzia-bozego.html (dostęp: 20.09.2016). http://www.diecezja.wloclawek.pl/pl/news/16,komunikaty/2300,biskup-wloclawski-wyznaczyl-koscioly-jubileuszowe-na-czas-obchodow-nadzwyczajnego-roku-swietego-milosierdzia (dostęp: 12.12.2016).

http://www.archidiecezja.wroc.pl/pliki/dekret-odpusty_w_Roku_Milosierdzia.pdf (dostęp: 12.12.2016).

http://www.diecezja.zamojskolubaczowska.pl/art722737,100-962 (dostęp: 20.09.2016). https://ordynariat.wp.mil.pl/plik/file/NS/521.pdf (dostęp: 20.09.2016).

Franciszek Mróz, dr Instytut Geografii

Uniwersytet Pedagogiczny w Krakowie 